\title{
VOLUME OF POLYETHYLENE BAGS FOR DEVELOPMENT OF PAPAYA SEEDLINGS IN PROTECTED ENVIRONMENTS
}

\author{
TATIANE A. C. FARIA ${ }^{1}$, EDILSON COSTA ${ }^{2}$, LETÍCIA C. DE OLIVEIRA ${ }^{1}$, \\ TIAGO L. DO ESPÍRITO SANTO ${ }^{1}$, ARTHUR P. DA SILVA ${ }^{1}$
}

\begin{abstract}
The objective of this study was to test container of polyethylene bags and protected environments on the papaya seedlings production, from May to August of 2008, in Aquidauana state of Mato Grosso do Sul (MS), Brazil. Five bags of polyethylene were used: $7.5 \mathrm{~cm}$ x $11.5 \mathrm{~cm}$, $205.9 \mathrm{~cm}^{3} ; 8.4 \mathrm{~cm} \mathrm{x} 10.6 \mathrm{~cm}, 238.1 \mathrm{~cm}^{3} ; 10.0 \mathrm{~cm} \times 16.5 \mathrm{~cm}, 525.2 \mathrm{~cm}^{3} ; 12.0 \mathrm{~cm} \mathrm{x} 12.0 \mathrm{~cm}$, $550.0 \mathrm{~cm}^{3}$ and $15.0 \mathrm{~cm} \times 21.5 \mathrm{~cm}, 1539.8 \mathrm{~cm}^{3}$. These containers were placed in three protected environments: greenhouse; screened nursery with Sombrite ${ }^{\circledR}$ and screened nursery with Aluminet ${ }^{\circledR}$. Because there is no replication of growing environment, each one was considered an experiment. For each cultivation environment, it was adopted a completely randomized design with eight replications of two plants each. Initially, data were submitted to analysis of individual variance of the container (for each cultivation environment), then performing the evaluation of the residual mean squares and the combined analysis of these environments for comparison of protected environments. The greenhouse and nursery with thermal reflector screen produced the best seedlings. The bags of $15.0 \times 21.5 \mathrm{~cm}$ produced the best papaya seedlings. The Dickson Quality Index pointed the nursery with screen of thermal reflector as the environment that produced the most vigorous seedlings, when using the best container.
\end{abstract}

KEYWORDS: Sunrise solo, containers, seedlings production.

\section{VOLUMES DE SACOLAS DE POLIETILENO NO DESENVOLVIMENTO DE MUDAS DE MAMOEIRO EM AMBIENTES PROTEGIDOS}

RESUMO: O objetivo deste trabalho foi testar sacos de polietileno e ambientes protegidos na produção de mudas de mamoeiro, de maio a agosto de 2008, em Aquidauana - MS. Foram utilizadas cinco dimensões de sacos de polietileno: $7,5 \mathrm{~cm}$ x $11,5 \mathrm{~cm}, 205,9 \mathrm{~cm}^{3} ; 8,4 \mathrm{~cm}$ x $10,6 \mathrm{~cm}$, $238,1 \mathrm{~cm}^{3} ; 10,0 \mathrm{~cm} \times 16,5 \mathrm{~cm}, 525,2 \mathrm{~cm}^{3} ; 12,0 \mathrm{~cm} \times 12,0 \mathrm{~cm}, 550,0 \mathrm{~cm}^{3}$, e $15,0 \mathrm{~cm} \times 21,5 \mathrm{~cm}$, $1.539,8 \mathrm{~cm}^{3}$. Estes recipientes foram acomodados em três ambientes protegidos: estufa agrícola; viveiro telado com Sombrite ${ }^{\circledR}$ e viveiro telado com Aluminet ${ }^{\circledR}$. Por não haver repetição do ambiente de cultivo, cada um foi considerado um experimento. Para cada ambiente de cultivo, foi adotado o delineamento experimental inteiramente casualizado, com oito repetições de duas plantas cada. Inicialmente, os dados foram submetidos às análises de variâncias individuais dos recipientes (para cada ambiente de cultivo), realizando-se em seguida a avaliação dos quadrados médios dos resíduos e a análise conjunta dos experimentos para a comparação dos ambientes protegidos. A estufa agrícola e o telado de termorrefletora produziram as melhores mudas. O recipiente de 15,0 x $21,5 \mathrm{~cm}$ produziu as melhores mudas do mamoeiro. O índice de qualidade de Dickson apontou o telado de termorrefletora como ambiente que produziu muda mais vigorosa quando se utilizou o melhor recipiente.

PALAVRAS-CHAVE: Sunrise solo, recipientes, produção de mudas.

\footnotetext{
${ }^{1}$ Graduando, UEMS, Unidade de Aquidauana - MS, tatianecurim@hotmail.com (PIBIC/UEMS), leticia_agroaqui@hotmail.com (PIBIC/UEMS), tiagropec@ hotmail.com (PIBIC/UEMS/CNPq), arthur_silva15@ hotmail.com (PIBIC/UEMS) .

${ }^{2}$ Prof. Doutor, UEMS, Unidade de Cassilândia - MS, mestrine@uems.br.

Recebido pelo Conselho Editorial em: 13-10-2011
}

Aprovado pelo Conselho Editorial em: 11-9-2012 


\section{INTRODUCTION}

In Mato Grosso do Sul, fruit production is low and most of the products are imported from other states, particularly São Paulo and Paraná, according to CEASA in Campo Grande - State of Mato Grosso do Sul (BOLETIM ANUAL, 2010) and there is, therefore, a need for research in all phases of production chain and cycle of fruit in the state.

In the supply chain, producing seedlings is critical, because high quality seedlings can generate adult plants with higher field productive potential (FRANCO \& PRADO, 2008). The need for renewal of orchards opens the possibility of new technologies in the sector of seedlings production, making essential research in this area (LIMA et al., 2007). RIBEIRO et al. (2005) point out that the production of high quality seedlings is one of the strategies used for those who want to produce and export.

To obtain seedlings of quality, the systems used in production are of great relevance, since the quality of the seedling directly affects their performance on the field. The use of structures for protection of seedlings is of great importance, because seedlings coming from protected environments may better adapt to the field, if well handled. The different environments of protected cultivation use, mostly, the film of low density polyethylene (greenhouses), however shade screens, such as monofilaments (Sombrite ${ }^{\circledR}$ ) and thermal reflector (Aluminet ${ }^{\circledR}$ ), are widely used (COSTA et al., 2010a). These types of environments favor the growing in containers, as they allow better management of both water and nutrients.

The dimensions and volume of the container influence seedlings early development and final quality, final cost of production, amount of substrate and input used, space occupied in the production environment, type of manpower and its transportation. Regarding the quality of the seedlings, MENDONÇA et al. (2003) found the polyethylene bags of $750 \mathrm{~mL}$ to provide better vigor for papaya seedlings than tubes of $50 \mathrm{~mL}$, and, according to ARAÚJO et al. (2006), bags of $20 \times 32 \mathrm{~cm}$ provide greater heights of papaya seedlings compared to $15.0 \times 20.0 \mathrm{~cm}$.

Containers with higher volume tend to have the best seedling development, as they provide more space for the root system, as well as higher amounts of nutrients. Polyethylene bags of $15.0 \mathrm{x}$ $25.0 \mathrm{~cm}\left(1,800 \mathrm{~cm}^{3}\right)$, compared to polystyrene trays of 72 cells $(5.0 \mathrm{~cm}$ wide by $12.0 \mathrm{~cm}$ height and volume of $121.2 \mathrm{~cm}^{3}$ per cell) provided better growth and development to papaya seedlings and passion fruit (COSTA et al., $2009 \mathrm{a}, \mathrm{b}$ ), evidencing that the greatest volume provided the best conditions for seedling development.

Other studies with seedling production report the influence of container volume in seedling development, where the largest volume of container, with the largest quantity of substrate, provides better seedlings. CARVALHO FILHO et al. (2003) found that polyethylene bags of $15.0 \times 20.0 \mathrm{~cm}$ $(1,432.39 \mathrm{~mL})$ promoted better seedlings of jatobá (Hymenaea courbaril L.) than the ones of $11.0 \mathrm{x}$ $18.0 \mathrm{~cm}(693.28 \mathrm{~mL})$, as well as VALLONE et al. (2009) observed that polythene bags of $10.0 \mathrm{x}$ $20.0 \mathrm{~cm}(700 \mathrm{~mL})$, compared with tubes of 50 and $120 \mathrm{~mL}$, provided better coffee seedlings (Coffea arabica L.).

Given the above, this study aimed to evaluate the formation of papaya seedlings in polyethylene containers of different sizes and volumes in different environments of protected cultivation in the region of Aquidauana - MS, Brazil.

\section{MATERIAL AND METHODS}

The experiments were conducted from May to August 2008 at the experimental area of the State University of Mato Grosso do Sul - UEMS in Aquidauana - MS, located at $174 \mathrm{~m}$ altitude, longitude $55.67^{\circ} \mathrm{W}$ and latitude $20.45^{\circ} \mathrm{S}$, region of interface between the Cerrado and Pantanal. It was produced papaya seedlings of Sunrise solo cultivar in five dimensions of plastic bags of: $7.5 \mathrm{~cm}$ x $11.5 \mathrm{~cm}, 205.9 \mathrm{~cm}^{3}(\mathrm{R} 1) ; 8.4 \mathrm{~cm}$ x $10.6 \mathrm{~cm}, 238.1 \mathrm{~cm}^{3}(\mathrm{R} 2) ; 10.0 \mathrm{~cm}$ x $16.5 \mathrm{~cm}, 525.2 \mathrm{~cm}^{3}(\mathrm{R} 3)$; $12.0 \mathrm{~cm} \mathrm{x} 12.0 \mathrm{~cm}, 550.0 \mathrm{~cm}^{3}$ (R4) and $15.0 \mathrm{~cm} \mathrm{x} 21.5 \mathrm{~cm}, 1539.8 \mathrm{~cm}^{3}$ (R5). 
These containers were accommodated in three protected environments: arch greenhouse ( $8.00 \mathrm{~m} \times 18.00 \mathrm{~m} \times 4.00 \mathrm{~m}$ ) of galvanized steel structure, with zenith opening on the ridge, covered with $150 \mu \mathrm{m}$ polyethylene film, light diffuser, having thermal reflector screen of $50 \%$ in the film and front and side locks of monofilament screen, mesh for $50 \%$ shade (A1); nursery, of galvanized steel structure $(8.00 \mathrm{~m} \times 18.00 \mathrm{~m} \times 3.50 \mathrm{~m})$, black monofilament screen of $50 \%$ shading $\left(\right.$ Sombrite $\left.{ }^{\circledR}\right)$, closed at $45^{\circ}$ degrees (A2), and nursery, of galvanized steel structure $(8.00 \mathrm{~m} \mathrm{x}$ $18.00 \mathrm{~m} \times 3.50 \mathrm{~m}$ ) thermal reflector screen of $50 \%$ shading (Aluminet ${ }^{\circledR}$ ), closed at $45^{\circ}$ degrees (A3).

Because there is no repetition in the culture environment, each one was considered an experiment. In each environment it was adopted a completely randomized design with eight replicates of two plants each. Initially, the data were submitted to analysis of variance of individual containers, and then it was performed the evaluation of the mean squares of the residue (BANZATTO \& KRONKA, 2006) and combined analysis of experiments to compare the cultivation environments. It was used the statistical program Sisvar 5.3 (FERREIRA, 2010), and means were compared by Tukey test at $5 \%$ probability.

The substrate used was composed of $86 \%$ soil (Alfissol) and $14 \%$ of Organosuper ${ }^{\circledR}$ (organic compost made from slaughterhouse residues, sugarcane bagasse, fruit, vegetables, cereals, etc.) being composted for 30 days. They were fertilized with $432 \mathrm{~g}$ of $\mathrm{KCl}, 3,600 \mathrm{~g}$ of dolomite lime (PRNT, 100\% PRNT) and 2,160 $\mathrm{g}$ of $\mathrm{P}_{2} \mathrm{O}_{5}$ per $\mathrm{m}^{3}$ of substrate. Irrigation was done manually with watering can, twice a day, morning and evening, when necessary, until saturation of the substrate, as observed by the beginning of superficial drainage of water, checked visually.

It was performed sowing of two seeds per container in May 15th, and the thinning was performed 30 days after seeding (DAS) when the seedlings had two true leaves. At 78 DAS after sowing it was measured: plant height $(\mathrm{PH})$ of the base of the substrate to apical bud, with a millimeter ruler; stem diameter (SD) on the base of the substrate with a digital caliper (mm graduation, full scale of $200 \mathrm{~mm}$ and accuracy of $0.01 \mathrm{~mm}$ ), shoot dry weight (SDW) and root dry weight (RDW) with analytical balance ( $\mathrm{g}$ graduation, full scale of $210 \mathrm{~g}$ and precision of $0.0001 \mathrm{~g}$ ), after drying in forced circulation oven at $65^{\circ} \mathrm{C}$, by the method of constant weight.

It was determined the ratio of dry weight shoot.root ${ }^{-1}$ (RSRDW), the relation between height and diameter (RHD) and Dickson quality index (DQI):

$$
\mathrm{DQI}=\frac{\mathrm{TDW}(\mathrm{g})}{\frac{\mathrm{PH}(\mathrm{cm})}{\mathrm{SD}(\mathrm{mm})}+\frac{\mathrm{SDW}(\mathrm{g})}{\mathrm{RDW}(\mathrm{g})}}
$$

In the period from May 15th to August 1st, 2008, meteorological data were obtained from the automatic station AQUIDAUANA-A719 from the National Institute of Meteorology (INMET/SONABRA) that are recorded every hour. Mean air temperature, mean relative humidity, accumulated precipitation and radiation were $22.0^{\circ} \mathrm{C}, 69.9 \%, 93 \mathrm{~mm}$ and $1,161.2 \mathrm{~kJ} \mathrm{~m}^{-2}$, respectively. The mean air temperatures from 4 to $6 \mathrm{am}$, during the period, was $16.32{ }^{\circ} \mathrm{C}$, with the lowest recorded temperature on June 17 th with a value of $8.3^{\circ} \mathrm{C}$.

\section{RESULTS AND DISCUSSION}

Except for the root (RDW) and total (TDW) dry weight, for the other parameters evaluated in this study, the relation between the residue mean square (RMS) of individual analysis of variance of experiments did not exceed the ratio of 7:1 (Table 1), therefore allowing the realization of combined analysis of experiments (BANZATTO \& KRONKA, 2006) and comparison of culture environments. For RDW and TDW, it was evaluated the containers in each cultivation environment, and it was not possible to find what was the best environment for these variables. 
TABLE 1. Residues mean square in the individual analysis for plant height $(\mathrm{PH})$, stem diameter (SD), shoot dry weight (SDW), root dry weight (RDW), total dry weight (TDW), relation between height and diameter (RHD), relation between shoot and root dry weight (RSRDW) and Dickson quality index (DQI) for papaya seedlings. AquidauanaMS, 2008.

\begin{tabular}{cccccccccc}
\hline & PH & SD & SDW & RDW & TDW & RHD & RSRDW & DQI \\
\hline \multicolumn{7}{c}{ Mean square of residues of individual analysis of variance of substrates } \\
Greenhouse & 0.264 & 0.087 & 0.00017 & 0.00030 & 0.00048 & 0.018 & 0.022 & 0.00017 \\
Sombrite $\left.^{(}\right)$ & 0.469 & 0.070 & 0.00017 & 0.00002 & 0.00016 & 0.036 & 0.022 & 0.00001 \\
Aluminet $\left.^{(}\right)$ & 0.519 & 0.051 & 0.00033 & 0.00149 & 0.00275 & 0.059 & 0.018 & 0.00070 \\
RMS* & 1.963 & 1.710 & 1.994 & 17.353 & 17.296 & 3.341 & 1.209 & 4.040 \\
\hline
\end{tabular}

* RMS - ratio between the highest and lowest residual mean square in the individual analysis of the containers for each environment.

In the evaluation of the containers within each cultivation environment, it was found that the papaya seedlings exhibited greater heights, stem diameter and shoot and root dry weight in bags of $15.0 \times 21.5 \mathrm{~cm}$ (R5) in all environments (Table 2). Among the factors that could contribute to the growth and development of papaya (environments, containers and time of year), the volume of the container was that caused greater negative effect, where the seedlings obtained from R1, R2, R3 and R4 had compromised development, because the volume of the container was lower than the R5. Apart from the container, the time of year (winter), even though a region of high temperature (Aquidauana - MS), reaches low temperatures $\left(6\right.$ to $\left.10^{\circ} \mathrm{C}\right)$, which inhibits plant development.

As a result of lower volume, there was restricting root growth, and consequently of shoot growth, as well as the availability of nutrients in these containers. The container of higher volume produced better seedling, and it was in agreement with the results of MENDONÇA et al. (2003), COSTA et al. (2009a) and ARAÚJO et al. (2006) in papaya seedlings, RIBEIRO et al. (2005) and COSTA et al. (2009b) in seedlings of passion fruit, CARVALHO FILHO et al. (2003) in seedlings of JATOBÁ (Hymenaea courbaril L.) and VALLONE et al. (2009) in coffee seedlings (Coffea arabica L.). The results show that the size of the container influences the growth, development and initial quality of seedlings.

In Aluminet ${ }^{\circledR}$, the seedlings produced in bags of $15.0 \times 21.5 \mathrm{~cm}(\mathrm{R} 5)$ showed no differences in root dry weight from seedlings grown in bags of $10.0 \mathrm{~cm} \times 16.5 \mathrm{~cm}$ (R3) (Table 2). This result may be related to the length of the bag, as these two containers have the greatest lengths and greater availability for root growth.

TABLE 2. Plant height (PH), stem diameter (SD), shoot dry weight (SDW), and root dry weight (RDW) for papaya seedlings. Aquidauana - MS, 2008.

\begin{tabular}{|c|c|c|c|c|c|c|}
\hline & Greenhouse & Sombrite $\left.^{(}\right)$ & Aluminet $^{(\mathbb{B}}$ & Greenhouse & Sombrite $^{(\circledR)}$ & Aluminet $^{(\circledR)}$ \\
\hline ** & \multicolumn{3}{|c|}{ Plant height $(\mathrm{PH}), \mathrm{cm}$} & \multicolumn{3}{|c|}{ Stem diameter (SD), $\mathrm{mm}$} \\
\hline R1 & $7.03 \mathrm{Ca}^{*}$ & $5.69 \mathrm{Cb}$ & $5.29 \mathrm{Db}$ & $3.69 \mathrm{Da}$ & $2.04 \mathrm{CDb}$ & $1.81 \mathrm{Db}$ \\
\hline $\mathrm{R} 2$ & $10.94 \mathrm{Ba}$ & $8.51 \mathrm{Bb}$ & $9.24 \mathrm{Cb}$ & $5.25 \mathrm{Ba}$ & $3.23 \mathrm{Bb}$ & $3.65 \mathrm{Cb}$ \\
\hline R3 & $10.78 \mathrm{Ba}$ & $7.90 \mathrm{Bb}$ & $10.66 \mathrm{Ba}$ & $5.60 \mathrm{Ba}$ & $2.48 \mathrm{Cc}$ & $4.72 \mathrm{Bb}$ \\
\hline $\mathrm{R} 4$ & $6.78 \mathrm{Ca}$ & $3.80 \mathrm{Dc}$ & $5.16 \mathrm{Db}$ & $4.60 \mathrm{Ca}$ & $1.89 \mathrm{Db}$ & $2.15 \mathrm{Db}$ \\
\hline \multirow[t]{2}{*}{$\mathrm{R} 5$} & $14.65 \mathrm{Aa}$ & $11.71 \mathrm{Ab}$ & $13.60 \mathrm{Aa}$ & $7.33 \mathrm{Aa}$ & $4.46 \mathrm{Ac}$ & $5.46 \mathrm{Ab}$ \\
\hline & \multicolumn{3}{|c|}{ Shoot dry weight (SDW), g } & \multicolumn{3}{|c|}{ Root dry weight (RDW), g } \\
\hline $\mathrm{R} 1$ & $0.108 \mathrm{Da}$ & $0.050 \mathrm{Cb}$ & $0.038 \mathrm{~Eb}$ & $0.132 \mathrm{~B}$ & $0.107 \mathrm{~B}$ & $0.040 \mathrm{~B}$ \\
\hline $\mathrm{R} 2$ & $0.220 \mathrm{Ca}$ & $0.090 \mathrm{Bb}$ & $0.112 \mathrm{Cb}$ & $0.100 \mathrm{BC}$ & $0.035 \mathrm{D}$ & $0.081 \mathrm{~B}$ \\
\hline R3 & $0.274 \mathrm{Bb}$ & $0.053 \mathrm{Cc}$ & $0.582 \mathrm{Ba}$ & $0.077 \mathrm{C}$ & $0.068 \mathrm{C}$ & $0.483 \mathrm{~A}$ \\
\hline $\mathrm{R} 4$ & $0.103 \mathrm{Da}$ & $0.036 \mathrm{Cc}$ & $0.069 \mathrm{Db}$ & $0.092 \mathrm{C}$ & $0.010 \mathrm{E}$ & $0.072 \mathrm{~B}$ \\
\hline $\mathrm{R} 5$ & $0.598 \mathrm{Ab}$ & $0.523 \mathrm{Ac}$ & $0.832 \mathrm{Aa}$ & $0.314 \mathrm{~A}$ & $0.261 \mathrm{~A}$ & $0.535 \mathrm{~A}$ \\
\hline
\end{tabular}

* Same uppercase letters in the columns and lowercase letters in the rows, for each variable, do not differ by Tukey test at 5\% probability. ${ }^{* *} \mathrm{R}$ - container 
Evaluating cultivation environments for each container, it was verified that seedlings grown in greenhouse conditions showed greater height, stem diameter and shoot dry weight than those grown in other environments, when using bags of $7.5 \mathrm{~cm} \mathrm{x} 11.5 \mathrm{~cm}(\mathrm{R} 1) ; 8.4 \mathrm{~cm} \times 10.6 \mathrm{~cm}$ (R2) and $12.0 \mathrm{~cm} \times 12.0 \mathrm{~cm}(\mathrm{R} 4)$. For bags of $10.0 \mathrm{~cm} \times 16.5 \mathrm{~cm}(\mathrm{R} 3)$ plants produced in the greenhouse showed greater stem diameter, but its height and shoot dry weight did not differ from seedlings grown in Aluminet ${ }^{\circledR}$ (Table 2).

To the seedlings produced in bags of $15.0 \mathrm{~cm}$ x $21.5 \mathrm{~cm}$ (R5), plants heights were similar in the greenhouse and in Aluminet ${ }^{\circledR}$, however, plants with larger diameter were observed in the greenhouse and with increased shoot dry weight in Aluminet ${ }^{\circledR}$ (Table 2). In the experiment conducted from November to January with different substrates for formation of papaya seedlings in bags of $15.0 \mathrm{~cm} \times 21.5 \mathrm{~cm}$, COSTA et al. (2010a) found that greenhouse environments, Aluminet ${ }^{\circledR}$ and Sombrite ${ }^{\circledR}$ did not differ. It is observed that both the volume of the container and the substrate interacts with environmental conditions (type of environment) and time of year to provide the best conditions for the development of the seedling.

In both environments, greenhouse and Aluminet ${ }^{\circledR}$, provide the best conditions for the development of the seedlings at the time of this present experiment. Because it was winter season, where the mean temperature of the experimental period was $22.0^{\circ} \mathrm{C}$, the polyethylene film garnered greater amount of thermal energy inside the greenhouse (CUNHA \& ESCOBEDO, 2003), which likely promoted greater air and substrate heating and better conditions for the development of papaya seedlings. The thermal reflector screen promoted greater internal diffusion of radiation, depending on the aluminized characteristics of twisted yarns fabric (LEITE et al., 2008), which made the plants grown in bags of $15.0 \mathrm{~cm} \times 21.5 \mathrm{~cm}$ (R5) extend their photosynthetic efficiency and to produce greater shoot dry weight. Allied to greater internal diffusion, GUISELINI et al. (2010) point out that this type of screen provides higher temperature in the winter, during which this study was developed.

In Sombrite ${ }^{\circledR}$, A2 environment, it was observed the lowest developed of seedlings in containers with smaller volume (Table 2). For not having the same properties of thermal energy conservation of the polyethylene film in the greenhouse and of the Aluminet ${ }^{\circledR}$ screen thermal reflector, in this environment, possibly did not store sufficient thermal energy for the proper development of the seedlings during the winter season (from May to August). However, in formation of papaya seedlings in periods of higher temperature, from September to November (spring), COSTA et al (2010b) observed better seedlings in the Sombrite ${ }^{\circledR}$ than in the greenhouse.

The highest total dry weight, as observed for shoot and root dry weight, were observed in the plants grown in the container of highest volume (R5), in all cultivation environments, as well as greater vigor expressed by Dickson Quality Index (DQI) (Table 3). It is noted again that the size of the container for seedling formation must be compatible with the characteristics of the type of seedling to be formed. For the papaya through variable height we found that the polyethylene bag with larger volume $\left(1,539.8 \mathrm{~cm}^{3}\right)$ led to a desired characteristic for future seedlings to be planted in the field, as well as could be observed with the variables of biomass. The bag of $15.0 \times 21.5 \mathrm{~cm}$ allowed higher accumulation of biomass, especially of dry weight. The greater availability of nutrients, due to higher volume, resulted in higher dry weight accumulation through the accumulation of carbohydrates, minerals, proteins, fibers and lipids in papaya seedlings. For papaya, this result of higher volume of the container is in agreement with the results obtained by MENDONÇA et al. (2003), ARAÚJO et al. (2006), COSTA et al. (2009a) and COSTA et al. (2010a). 
TABLE 3. Total dry weight (TDW), relation between height and diameter (RHD), relation between shoot and root dry weight (RSRDW) and Dickson quality index (DQI) for papaya seedlings. Aquidauana - MS, 2008.

\begin{tabular}{|c|c|c|c|c|c|c|}
\hline & Greenhouse & Sombrite $\left.^{(}\right)$ & Aluminet $^{(\circledR)}$ & Greenhouse & Sombrite $^{(\circledR)}$ & Aluminet $^{(B)}$ \\
\hline$* *$ & \multicolumn{3}{|c|}{ Total dry weight (TDW), g } & \multicolumn{3}{|c|}{ Relation height and diameter (RHD) } \\
\hline $\mathrm{R} 1$ & $0.240 \mathrm{C}^{*}$ & $0.157 \mathrm{~B}$ & $0.078 \mathrm{C}$ & $1.92 \mathrm{Ab}$ & $2.79 \mathrm{ABa}$ & $2.93 \mathrm{Aa}$ \\
\hline $\mathrm{R} 2$ & $0.320 \mathrm{~B}$ & $0.125 \mathrm{C}$ & $0.192 \mathrm{C}$ & $2.08 \mathrm{Ab}$ & $2.64 \mathrm{Ba}$ & $2.54 \mathrm{Ba}$ \\
\hline R3 & $0.351 \mathrm{~B}$ & $0.121 \mathrm{C}$ & $1.065 \mathrm{~B}$ & $1.93 \mathrm{Ac}$ & $3.18 \mathrm{Aa}$ & $2.27 \mathrm{Bb}$ \\
\hline $\mathrm{R} 4$ & $0.194 \mathrm{C}$ & $0.046 \mathrm{D}$ & $0.141 \mathrm{C}$ & $1.47 \mathrm{Bc}$ & $2.03 \mathrm{Cb}$ & $2.41 \mathrm{Ba}$ \\
\hline \multirow[t]{2}{*}{$\mathrm{R} 5$} & $0.913 \mathrm{~A}$ & $0.784 \mathrm{~A}$ & $1.367 \mathrm{~A}$ & $2.00 \mathrm{Ab}$ & $2.63 \mathrm{Ba}$ & $2.49 \mathrm{Ba}$ \\
\hline & \multicolumn{3}{|c|}{ Relation shoot and root dry weight (RSRDW) } & \multicolumn{3}{|c|}{ Dickson quality index (DQI) } \\
\hline R1 & $0.82 \mathrm{Ea}$ & $0.47 \mathrm{~Eb}$ & $0.95 \mathrm{Ca}$ & $0.087 \mathrm{Ba}$ & $0.048 \mathrm{Bb}$ & $0.020 \mathrm{Bb}$ \\
\hline $\mathrm{R} 2$ & $2.22 \mathrm{Bb}$ & $2.61 \mathrm{Ba}$ & $1.40 \mathrm{Abc}$ & $0.074 \mathrm{Ba}$ & $0.024 \mathrm{BCb}$ & $0.049 \mathrm{Bab}$ \\
\hline R3 & $3.56 \mathrm{Aa}$ & $0.79 \mathrm{Dc}$ & $1.22 \mathrm{BCb}$ & $0.064 \mathrm{Bb}$ & $0.030 \mathrm{BCc}$ & $0.308 \mathrm{Aa}$ \\
\hline $\mathrm{R} 4$ & $1.14 \mathrm{Db}$ & $3.82 \mathrm{Aa}$ & $0.95 \mathrm{Cb}$ & $0.075 \mathrm{Ba}$ & $0.008 \mathrm{Cc}$ & $0.042 \mathrm{Bb}$ \\
\hline R5 & $1.92 \mathrm{Ca}$ & $2.01 \mathrm{Ca}$ & $1.56 \mathrm{Ab}$ & $0.234 \mathrm{Ab}$ & $0.169 \mathrm{Ab}$ & $0.339 \mathrm{Aa}$ \\
\hline
\end{tabular}

* Same uppercase letters in the columns and lowercase letters in the rows, for each variable, do not differ by Tukey test at $5 \%$ probability. ** $\mathrm{R}$ - container

The period was more favorable to the development of seedlings in the greenhouse and Aluminet $^{\circledR}$ (Table 3) as they promote better conservation of thermal energy, since the average temperature was $22.0{ }^{\circ} \mathrm{C}$. The roofing material was one of the factors that affected the growth and development of papaya seedlings, together with the volumes of the containers. These materials induced variations in the internal microclimate of the protected environments, especially in its attenuating solar radiation and spectral distribution (COSTA \& LEAL, 2011), which was $1,161.2 \mathrm{~kJ} \mathrm{~m}^{-2}$, as well as the use of lateral screens in the distribution of environment internal temperature (DUARTE et al., 2011).

The changes caused by roofing and lateral materials influence plant physiology (CHAVARRIA et al., 2009) and minimized the spread of diseases (CHAVARRIA et al., 2007), depending on the proper management applied to the greenhouse environment. Besides these aspects, CARDOSO et al. (2008) observed a reduction in evaporative demand of wineries plants in protected cultivation environments.

\section{CONCLUSIONS}

The greenhouse and the nursery with thermal reflector screen produced the best seedlings with high quality and vigor.

The container of largest volume (polyethylene bag of $15.0 \times 21.5 \mathrm{~cm}$ ) produced the best seedlings of papaya.

The Dickson quality index pointed the nursery with thermal reflector screen as the environment that produced more vigorous seedlings when using the best container.

\section{REFERENCES}

ARAÚJO, J. R. G.; ARAÚJO JÚNIOR, M. M.; MENEZES, R. H. N.; MARTINS M. R.; LEMOS, R. N. S.; CERQUEIRA M. C. M. Efeito do recipiente e ambiente de cultivo sobre o desenvolvimento de mudas de mamoeiro cv. Sunrise solo. Revista Brasileira de Fruticultura, Jaboticabal, v.28, n.3, p.526-529, 2006.

BANZATTO, D. A.; KRONKA, S. N. Experimentação agrícola. 4. ed. Jaboticabal: Funep, 2006. $237 \mathrm{p}$. 
BOLETIM ANUAL 2011. Comercialização anual da CEASA/MS em 2010. Campo Grande-MS: Governo do Estado, 2011. Disponível em: <www.ceasa.ms.gov.br>. Acesso: em 15 maio 2011.

CARDOSO, L. S.; BERGAMASCHI, H; COMIRAN, F.; CHAVARRIA, G.; MARODIN, G.A.B.; DALMAGO, G. A.; SANTOS, H. P. dos; MANDELL, F. Alterações micrometeorológicas em vinhedos pelo uso de coberturas de plástico. Pesquisa Agropecuária Brasileira, Brasília, v.43, n.4, p.441-447, 2008.

CARVALHO FILHO, J. L. S. de; ARRIGONI-BLANK, M. de F.; BLANK, A. F.; RANGEL, M.S.A. Produção de mudas de jatobá (Hymenaea courbaril L.) em diferentes ambientes, recipientes e composições de substratos. CERNE, Lavras, v.9, n.1, p.111-121, 2003.

CHAVARRIA, G.; SANTOS, H. P. dos; SÔNEGO, O. R.; MARODIN, G. A. B.; BERGAMASCH, H.; CARDOSO, L. S. Incidência de doenças e necessidade de controle em cultivo protegido de videira. Revista Brasileira de Fruticultura, Jaboticabal, v.29, n.3, p.477-482, 2007.

CHAVARRIA, G.; CARDOSO, L. S.; BERGAMASCH, H.; SANTOS, H. P. dos; MANDELLI, F.; MARODIN, G. A. B. Microclima de vinhedos sob cultivo protegido. Ciência Rural, Santa Maria, v.19, n.7, p.2029-2034, 2009.

COSTA, E.; SANTOS, L. C. R.; VIEIRA, L. C. R. Produção de mudas de mamoeiro utilizando diferentes substratos, ambientes de cultivo e recipientes. Engenharia Agrícola, Jaboticabal, v.29, n.4, p.528-537, 2009a.

COSTA E.; RODRIGUES E. T.; ALVES, V. B.; SANTOS, L. C. R.; VIEIRA, L. C. R. Efeitos da ambiência, recipientes e substratos no desenvolvimento de mudas de maracujazeiro-amarelo em Aquidauana - MS. Revista Brasileira de Fruticultura, Jaboticabal, v.31, n.1, p.236-244, 2009b.

COSTA, E.; MESQUITA, V. A. G.; LEAL, P. A. M.; DORNELAS, C. F.; ABOT, A. R. Formação de mudas de mamão em ambientes de cultivo protegido em diferentes substratos. Revista Ceres, Viçosa, v.57, n.5, p.679-685, set./out. 2010a.

COSTA, E.; LEAL, P. A. M.; SANTOS, L. C. R. dos; VIEIRA, L. C. R. Crescimento de mudas de mamoeiro conduzidas em diferentes ambientes protegidos, recipientes e substratos na região de Aquidauana, Estado do Mato Grosso do Sul. Acta Scientiarum. Agronomy, Maringá, v.32, n.3, p.463-470, 2010b.

COSTA, E.; LEAL, P. A. M. Medidas radiométricas em casas de vegetação com cobertura plástica na região de Campinas - SP. Engenharia Agrícola, Jaboticabal, v.3, n.3, p.448-457, 2011.

CUNHA, A. R.; ESCOBEDO, J. F. Alterações micrometeorológicas causadas pela estufa plástica e seus efeitos no crescimento e produção da cultura de pimentão. Revista Brasileira de Agrometeorologia, Santa Maria, v.11, n.1, p.15-27, 2003.

DUARTE, L. A.; SCHÖFFEL, E. R; MENDEZ, M. E. G.; SCHALLENBERGER, E. Alterações na temperatura do ar mediante telas nas laterais de ambientes protegidos cultivados com tomateiro. Revista Brasileira de Engenharia Agrícola e Ambiental, Campina Grande, v.15, n.2, p.148-153, 2011.

FERREIRA, D. F. SISVAR - Sistema de análise de variância. Versão 5.3. Lavras: UFLA, 2010.

FRANCO, C. F.; PRADO, R. M. Nutrição de micronutrientes em mudas de goiabeira em resposta ao uso de soluções nutritivas. Acta Scientiarum. Agronomy, Maringá, v.30, n.3, p.403-408, 2008.

GUISELINI, C.; SENTELHAS, P. C.; PANDORFI, H.; HOLCMAN, E. Manejo da cobertura de ambientes protegidos: radiação solar e seus efeitos na produção da gérbera. Revista Brasileira de Engenharia Agrícola e Ambiental, Campina Grande, v.14, n.6, p.645-652, 2010.

LEITE, C. A.; ITO, R. M.; LEE, G. T. S.; GANELEVIN, R.; FAGNANI, M. A. Light spectrum management using colored nets to control the growth and blooming of phalaenopsis. Acta Horticulturae, The Hague, v.770, p.177-184, 2008. 
LIMA, J. F.; PEIXOTO, C. P.; LEDO, C. A. S. Índices fisiológicos e crescimento inicial de mamoeiro (Carica papaya L.) em casa de vegetação. Ciência e Agrotecnologia, Lavras, v.31, n.5, p. 1358-1363, 2007.

MENDONÇA, V.; ARAÚJO NETO, S. E.; RAMOS, J. D.; PIO, R.; GONTIJO, T. C. A. Diferentes substratos e recipientes na formação de mudas de mamoeiro 'Sunrise solo'. Revista Brasileira de Fruticultura, Jaboticabal, v.25, n.1, p.127-130, 2003.

RIBEIRO, M. C. C.; MORAIS, M. J. A.; SOUSA, A. H.; LINHARES, P. C. F.; BARROS JUNIOR, A. P. Produção de mudas de maracujá-amarelo com diferentes substratos e recipientes. Caatinga, Mossoró, v.18, n.3, p.155-158, 2005.

VALLONE, H. S.; GUIMARÃES, R. J; MENDES, A. N. G; SOUZA, C. A. S.; DIAS, F. P.; CARVALHO, A. M. Recipientes e substratos na produção de mudas e no desenvolvimento inicial de cafeeiros após o plantio. Ciência e Agrotecnologia, Lavras, v.33, n.5, p.1327-1335, 2009. 